\title{
The Black Bird Gang
}

"crows break off from the rest of darkness" (Mary Oliver)

You speak of crow and

I will tell you of raven

his eye a bold black bead

his ruff of head feathers

a well-oiled pompador

his three-pronged talons

a scaly imprint

of his dinosaur relative

his beak a magnificant wedge

the profile of a roman emperor.

I will tell you he is trickster

who rides the wind

with such skill I mistake him

for soaring eagle,

yet on the street, he hops absurdly

sideways and swaggers with the strut

of a spaghetti western cowboy.

He lords it over us

showing off his ventriloquist voice

quicksilver shift from underwater gurgle

to commanding squawk,

yet he hangs out in the bed of a pick up

shoving his buddies aside

over garbage bags

like bored teenage boys. 
Come night, he's left town

rounded up his rowdy comrades returned to darkness

known only to him and his kind. I tell you he'll be back

freewheeling into town where he sideslips through

the windstream of our days

one steady eye

watching out for us. 